\title{
Triple-negative bilateral synchronous infiltrating lobular cancer in an elderly male: A rare case report
}

\author{
Sathiah P. ${ }^{1}$, Gochhait D. ${ }^{2 *}$
}

DOI: https://doi.org/10.17511/jopm.2020.i04.14

\footnotetext{
1 Prasath Sathiah, Assistant Professor, Department of Pathology, Trichy SRM Medical College Hospital and Research Center, Trichy, Tamil Nadu, India.

2* Debasis Gochhait, Associate Professor, Department of Pathology, Jawaharlal Institution of Postgraduate Medical Education and Research, Puducherry, India.
}

Breast malignancy in males is rare, because of the absence of lobules. Here we are presenting the case of 65 male patients presented with bilateral breast enlargement. On examination also shows a bilateral pleural effusion. Sonomammogram shows features of gynecomastia. A bone scan shows multiple skeletal metastases involving all over the body. Trucut biopsy from both breasts shows tumor with features of infiltrating lobular carcinoma. Immunohistochemistry revealed this tumor as triple-negative. Plural fluid cytology examination shows evidence of metastasis adenocarcinoma deposits.

Keywords: Breast cancer, Gynecomastia, Pleural effusion

Corresponding Author

Debasis Gochhait, Associate Professor, Department of Pathology, Jawaharlal Institution of Postgraduate Medical Education and Research, Puducherry, India. Email: anand84Prasath@yahoo.corr
How to Cite this Article

Sathiah P, Gochhait D. Triple-negative bilateral synchronous infiltrating lobular cancer in an elderly male: A rare case report. Trop J Pathol Microbiol. 2020;6(4):345-348.

Available From

https://pathology.medresearch.in/index.php/jopm/ar ticle/view/452
To Browse

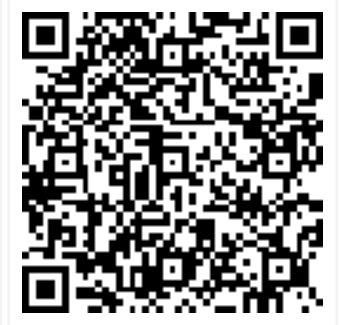

\section{Introduction}

Male breast cancer represents approximately $1 \%$ of all invasive breast cancer cases and less than $1 \%$ all malignancies in men [1]. Because of the absence of lobules in male chest, invasive lobular carcinoma very uncommon in male patients [2]. Here, we are going to present the cases of bilateral lobular carcinoma of a male patient.

\section{Case Report}

A case of the 65-year male patient came with
Chief complaints of difficulty in passing urine for 3 months. The patient also has complained of enlargement of both the breast with tenderness for 5 months. Local examination revealed the indurated mass with the size of 2.5 inches felt over the left breast which is mobile, not adherent. No well-defined mass felt on the right breast. No axillary node is palpable. Respiratory system examination shows a moderate pleural effusion. CVS and CNS examinations are normal.

Bilateral sonomammogram shows gynecomastia (Left> right) with diffuse,
Manuscript Received 03-03-2020

Conflict of Interest No

Review Round 1
$14-04-2020$
Funding
Nil

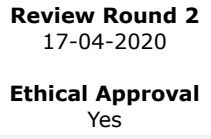

Review Round 3

Plagiarism X-checker $13 \%$
Accepted 22-04-2020

Note

(C) 2020 by Prasath Sathiah, Debasis Gochhait and Published by Siddharth Health Research and Social Welfare Society. This is an Open Access article licensed under a Creative Commons Attribution 4.0 International License https://creativecommons.org/licenses/by/4.0/ unported [CC BY 4.0]. 
Extensive inflammatory changes, and edema involving bilateral premammary fat zone. No focal abscess. USG abdomen and pelvis reveal gall bladder calculus(15mm), hepatomegaly, grade II prostatomegaly $(5 \times 4.6 \times 4.1 \mathrm{~cm}$ volume-50ml) with the intravesical extension. Also, the patient had bilateral hydroureteronephrosis.

Urine biochemical examination revealed a trace of protein. Microscopic examination revealed plenty of WBC, motile bacteria $(2+)$, and pus casts. Urine culture revealed Candida Albicans. Patients had a history of anterior wall myocardial infarction followed by PTCA to the left anterior descending artery and left circumflex artery done in 2012.

A bone scan revealed multiple skeletal metastases showing increased tracer uptake in occipital, cervical-dorsal-lumbar vertebra, sternum, bilateral multiple ribs, scapula, proximal femur, the shaft of the right femur, and pelvic bone.

Fine needle aspiration cytology of both breasts shows highly pleomorphic hyperchromatic atypical cells with scant cytoplasm. Advised to do trucut biopsy.

Trucut biopsy from both breasts shows infiltrating tumors of similar morphology arranged in cords and single-cell pattern with surrounding desmoplastic reaction. Tumor cells exhibit a moderate degree of nuclear anaplasia with some of the tumor cells exhibit signet-ring morphology. Tumor cells also are seen around the normal ductular unit (Targetoid pattern). Mucicarmine stain highlights the mucin in the signet ring cell (Figure 1). Immunohistochemistry performed, tumor cells were positive for Cytokeratin and negative for E-cadherin and Periodic acid-Schiff (PAS). Hormonal receptors (Estrogen receptor, progesterone receptor, and Her2Neu receptor) are negative in the tumor cells (Figure 2). Proliferation index (Ki-67) is 20\%. The final diagnosis given was bilateral infiltrating lobular carcinoma.

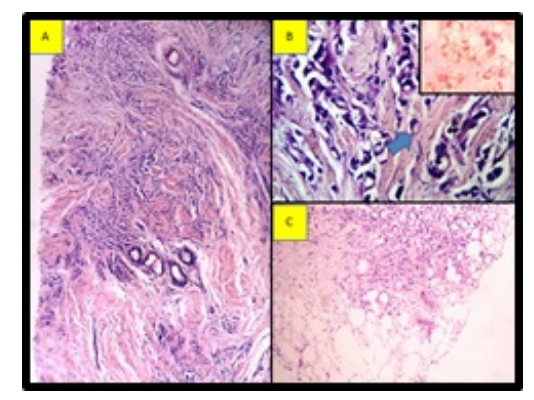

Fig-1: A. Trucut biopsy from the right breast shows infiltrating tumor arranged in cords and
Single-cell pattern with surrounding desmoplastic reaction. (H\&E, 100x) B. These tumor cells exhibit a moderate degree of nuclear anaplasia with some of the tumor cells exhibit signet ring morphology (arrow, H\&E, 400x) highlighted by mucicarmine stain in the inset(400x). C. Similar tumor in the left breast with adjacent fat infiltration (H\&E, 100x).

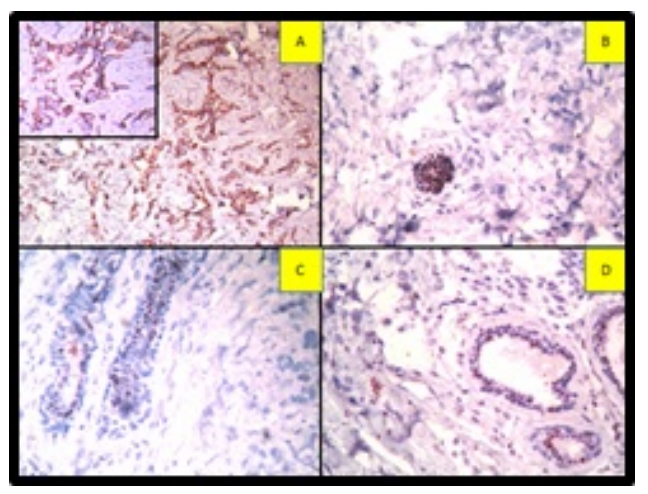

Fig-2: Tumour cells are positive for A. Cytokeratin (IHC, 100x) and the inset shows the same in high power (IHC, 400x). Negative for B. ER (IHC, 400x), C. PR, (IHC, 400x) and D. Her2Neu (IHC, 400x). (ER, PR, Her2Neu positive in the normal duct).

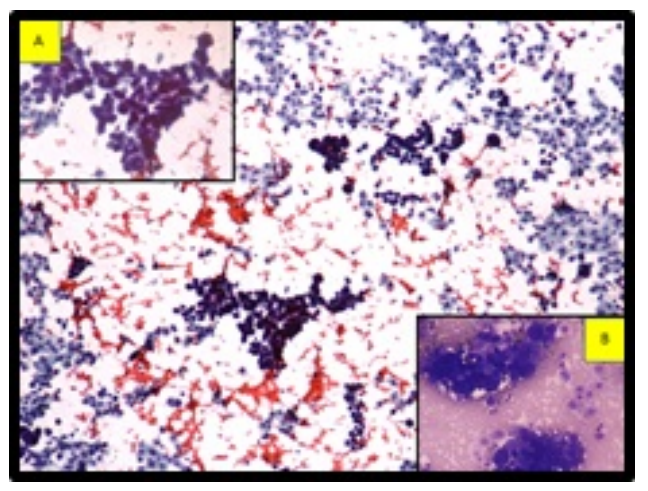

Fig-3: Pleural fluid smear shows tumor cells arranged in a vague glandular pattern (Pap, 100x). Inset $A$ shows the same in high power (Pap, 400x). Inset B shows the same finding in Giemsa stain (400x).

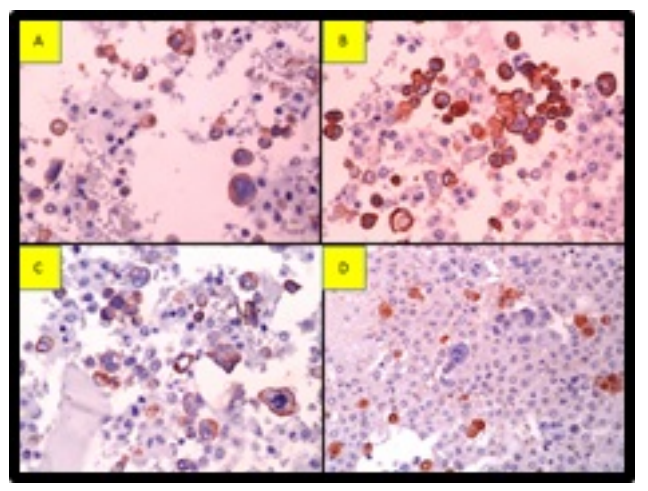


Fig-4: Tumour cells are positive for $A$. GCDFP (IHC, 400x), B. EMA (IHC, 400x), C. CK7(IHC, 400x) and Negative for Calretinin (IHC, 400x). Calretinin is positive in reactive mesothelial cells. (IHC has done on cell block preparation).

The pleural tap was done, revealed turbid hemorrhagic pleural fluid. Smears show features of metastatic adenocarcinoma (Figure 3). Immunocytochemistry was done on the cell block. Cells are positive for Cytokeratin 7 (CK 7), Gross Cystic Disease Fluid Protein-15(GCDFP), Epithelial membrane antigen (EMA), Carcinoembryonic antigen(CEA) and negative for Cytokeratin (CK20).

Calretinin is positive in reactive mesothelial cells (Figure 4). Correlating the morphology with the immunocytochemistry findings and history of carcinoma breast, the possibility of metastasis from the breast is to be considered.

\section{Discussion}

Breast carcinoma occurs in both genders. Although certain characteristics are similar for both genders, there are many differences in incidence, distribution of age, histological type, prognosis, and survival. Prognosis of male breast cancer is more unfavorable comparisons to the female patient because of presentation at an older age and advanced tumor stage at the time of diagnosis [1]. Our patients also presented at the age of 65 years.

The etiology of male breast cancer is unclear, however, there are many associations of breast cancer with testicular abnormalities such as undescended testes, orchitis, congenital inguinal hernia, and history of breast trauma [3].

Klinefelter's syndrome is present in $3-7 \%$ of men with breast cancer, and it increases the breast cancer risk 50-fold greater than the general male patient [4]. Chest wall radiation for Hodgkin's disease increases the subsequent cancer risk [3].

Pituitary prolactinoma also associated with male breast cancer, due to the effect of increased prolactin level which stimulates the breast tissue from premalignant to malignant. BRCA2 gene mutation carrier was more frequent, 4- 16\% identified in male breast cancer patients [5].

Our case not associated with any of the above diseases. Although gynecomastia was very common in healthy men, it also has been reported in association with breast cancer $[4,6,7]$. Common
Presenting symptoms of breast cancer patients are a painless subareolar lump, nipple retraction, and bleeding $[8,9]$. Our case also presents with swelling on both sides of the breast. As in females with breast cancer, male breast cancer also had a slight preponderance of the left side compared to the right side [10].

Data from a cancer registry in the Surveillance, Epidemiology, and End Results (SEER) in more than 2000 male patients show that ductal or unclassified carcinomas are common cancer identified in $93.7 \%$ of male breast cancer, remaining $2.6 \%$ are papillary, $1.8 \%$ are mucinous and only $1.5 \%$ are lobular [1].

This distribution is in contrast to female breast cancer, in which around $12 \%$ of cancers are lobular carcinoma. The highest percentage of lobular carcinoma (4.2\%) was noted with 612 male breast cancer from the Veterans Affairs Central Cancer Registry [11].

Hormonal receptors expression was higher in male breast cancer patients compared to female breast cancer and it also increases with age. Approximately, $90 \%$ of male breast cancer expressed the estrogen receptor and $81 \%$ expressed the progesterone receptor [1]. But, in contrast, the Her2 Neu receptor was less likely to be overexpressed in male breast cancer patients $[12,13]$. But our case is triple-negative.

Data from the Swedish Family-Cancer Database indicate male breast survivors had 93- fold greater risk of developing contralateral breast cancer compared to males without a history of breast cancer [14].

There was also the risk of developing other cancers, including melanoma and prostate cancer, particularly in mutation carriers [15]. Our patients had grade II prostatomegaly but PSA levelly is normal. Prostate biopsy not done for this patient.

Patients put on chemotherapy. But developed the sepsis during treatment and intubated due to respiratory distress and then subsequently died.

\section{Conclusion}

Bilateral male infiltrating lobular breast cancers was a very rare disease. So it is important to identify this type of breast cancer at an early stage and start the therapy as soon as possible for a better outcome. 


\section{Reference}

01. Goss PE, Reid C, Pintilie M, Lim R, Miller N. Male breast carcinoma- a review of 229 patients who presented to the Princess Margaret Hospital during 40 years- 1955-1996. Cancer. $1999 ; 85(3) 629-639$.

doi:[https://doi.org/10.1002/(sici)1097-0142(19

990201)85:3\%3C629: : aid-cncr13\%3E3.0.co;2-v]

[Crossref]

02. Yildirim E, Berberoglu U. Male breast cancer- a 22-year experience. Eur J Surg Oncol. $1998 ; 24(6) 548-552$.

doi:[https://doi.org/10.1016/s0748-7983(98)936083][Crossref]

03. Sanchez AG, Villanueva AG, Redondo C. Lobular carcinoma of the breast in a patient with Klinefelter's syndrome- A case with bilateral, synchronous, histologically different breast tumors. Cancer. 1986;57(6)1181-1183.

doi: [Article:https://doi.org/10.1002/10970142(19860315)57:6\%3C1181: :aidcncr2820570619\%3E3.0.co;2-t][Crossref]

04. Sasco AJ, Lowenfels $A B$, Pasker-de Jong $P$. Review article- epidemiology of male breast cancer- A meta-analysis of published casecontrol studies and discussion of selected aetiological factors. Int J Cancer. 1993;53(4)538-549.

doi: [Article:https://doi.org/10.1002/ijc.2910530403] [Crossref]

05. Giordano SH, Cohen DS, Buzdar AU, Perkins G, Hortobagyi GN. Breast carcinoma in men- a population?based study. Cancer. 2004;101(1)51-57.

doi:[https://doi.org/10.1002/cncr.20312][Crossref]

06. Basham VM, Lipscombe JM, Ward JM et al. BRCA1 and BRCA2 mutations in a populationbased study of male breast cancer. Breast Cancer Res. 2002;4(1)R2.

doi:[https://dx.doi.org/10.1186\%2Fbcr419]

[Crossref]

07. Nahleh ZA, Srikantiah R, Safa M, Jazieh AR, Muhleman A, Komrokji R. Male breast cancer in the veterans affairs population- a comparative analysis. Cancer. 2007;109(8)1471-1477.

doi:[https://doi.org/10.1002/cncr.22589][

Crossref]
08. Giordano SH, Buzdar AU, Hortobagyi GN. Breast cancer in men. Ann Intern Med. 2002;137(8)678-687.

doi:[https://doi.org/10.7326/0003-4819-137-8200210150-00013][Crossref]

09. Stierer M, Rosen $H$, Weitensfelder W, Hausmaninger $\mathrm{H}$, Teleky $\mathrm{B}$, Jakesz $\mathrm{R}$, et al. Male breast cancer- Austrian experience. World J Surg. 1995;19(5)687-692. doi:[https://doi.org/10.1007/BF00295904][Crossref]

10. Dong C, Hemminki K. Second primary breast cancer in men. Breast Cancer Res Treat. 2001;66(2)171-172.

doi:[https://doi.org/10.1023/a:1010639429207]

[Crossref]

11. Auvinen A, Curtis RE, Ron E. Risk of subsequent cancer following breast cancer in men. J Natl Cancer Inst. 2002;94(17)1330-1332. doi:[https://doi.org/10.1093/jnci/94.17.1330] [Crossref]

12. Muir D, Kanthan R, Kanthan SC. Male versus female breast cancers- A population-based comparative immunohistochemical analysis. Arch Pathol Lab Med. 2003;127(1)36-41. doi:[https://doi.org/10.1043/00039985(2003)127\%3C36:mvfb\%3E2.0.co;2][Crossref]

13. Bloom KJ, Govil H, Gattuso P, Reddy V, Francescatti D. Status of HER-2 in male and female breast carcinoma. Am J Surg. 2001;182(4)389-392. doi:[https://doi.org/10.1016/s0002-9610(01)007334][Crossref]

14. Scott-Conner CE, Jochimsen PR, Menck HR, Winchester DJ. An analysis of male and female breast cancer treatment and survival among demographically identical pairs of patients. Surg. 1999;126(4)775-780.

[Crossref] 